\title{
甲状腺疾患の画像診断
}

\author{
京都大学医学部核医学科
}

小西 淳二

\section{Diagnostic Imaging of the Thyroid}

Junji KONISHI, M.D.

Department of Nuclear Medicine, Faculty of Medicine, Kyoto University

Among various imaging modalities used for the diagnosis of thyroid diseases, ultrasonography is the most sensitive and economical method to visualize anatomic detail and structural relations. Scintigraphy using ${ }^{123} \mathrm{I}$ or ${ }^{99 m} \mathrm{Tc}$ gives critical information about thyroid cell function and makes it possible to differentiate the causes of thyrotoxicosis. Tumor scintigraphy using ${ }^{201} \mathrm{~T} 1,{ }^{67} \mathrm{Ga},{ }^{131} \mathrm{I}$-metaiodobenzyl guanidine or ${ }^{99 \mathrm{~m}} \mathrm{Tc}(\mathrm{V})$-dimercaptosuccinic acid is useful for the characterization of nodules. Recently introduced magnetic resonance imaging appears promising in demonstrating pseudocapsules around tumors and capsular invasion.

Key words : Ultrasonography, Thyroid cancer, Scintigraphy, X-ray CT, Magnetic resonance imaging

は じめに

甲状腺疾患の診断のために行われる画像検査法には表 1に示すような種々のものがある。これら の内，最近もっとも著しい進歩を遂げ，スクリーニングに不可欠の検査となったのは超音波断層法 である。超音波検査により形態異常が捉えられたとき，それが機能にどのような影響を与えている かを知るために甲状腺シンチグラフィを行ら。

腫瘤性病変の場合にはさらに第二段階の検査としてその性状を知るために頝部軟 X 線, 腫瘍シ ンチグラフィが行われる。X 線 CT や磁気共鳴画像 (MRI) では甲状腺腫瘍と周囲組織との関係, 特に超音波検査でわかりにくい深部の情報が得られる。以下，超音波検査を中心にこれらの画像診 断法で得られる情報の診断的意義について述べることにしたい。

1. 超音波断層法 (Ultrasonography : US)

超音波断層法 (US) は簡便で安価, かつ非侵襲的である上，最も感度に優れている ように体表面に近い臓器では分解能の高い高周波の探触子が用いられる。7.5MHz の電子走査式の リニア型探触子が使用されることが多い。顏部の表在組織は直接探触子をあてるだけでは十分密着 出来ないことが多く，前頝部に脱気水を入れたビニール袋をのせ，その中で探触子を操作する水浸 
法がよく用いられる2)。これにより，びまん性，結節性を問わず，甲状腺腫の大きさ，形，さらに 内部の性状など形態異常を明瞭に把握することができる。さらに繰り返して検査できるので経過の 観察にも適し, 日常診断上のメリットは極めて大きい。超音波装置による形態画像と甲状腺細胞の ヨード転送機能を反映する機能画像であるテクネチウム $-99 \mathrm{~m}$ シンチグラフィ（ヨード制限が不 要なのですぐに行える, 次項参照）との両者を, 初猃時もしくは再診時までの早い時期にみること は，迅速かつ的確な診断への第一歩であり，かつこれだけで多くの診断情報が得られる。言うまで もないことであるが, 甲状腺は表在性の臟器であるので, 触診によって多くの情報を得ることがで きる。専門医は触診のみでも甲状腺疾患の大半の診断が可能と言われるくらいで, 触診による局所 所見の把握のために経験を積み重ねていく必要があるが, これら2つの検査は, そのような所見を 裏付け，客観化してくれるとともに，見落としや判断の誤りをも明らかにしてくれる基本的な画像 診断法である。

表1. 甲状腺疾患の診断に用いられる画像診断法

I 、びまん性, 結節性甲状腺腫の一次検査

1)超音波断層法（US）

2) シンチグラフィ $\left({ }^{123} \mathrm{I},{ }^{99 \mathrm{~m}} \mathrm{TCO}_{4}^{-}\right)$

II. 腫瘤性病変の二次検査

1) 䫌部軟 $X$ 線

2)腫瘍シンチグラフィ

$\left({ }^{201} \mathrm{Tl},{ }^{131} \mathrm{I},{ }^{67} \mathrm{Ga},{ }^{131} \mathrm{I}-\mathrm{MIBG},{ }^{99 \mathrm{~m}} \mathrm{Tc}(\mathrm{V})\right.$-DMS)

3) X線 C T

4) 磁気共鳴画像（MRI）

びまん性の甲状腺腫大をみとめる場合，US の役割は以下のような点にある。

1）甲状腺腫大の程度を知る。甲状腺体積の計測にも応用されている3 ${ }^{3)}$ 。

2）潜在性結節の検出：特に最近の超音波装置の進歩による分解能の向上の結果, 触診ではわから ないような小結節や囊胞性病変が容易に見いだされるようになった。

3）慢性甲状腺炎では濾胞の崩壊が高度なものほどエコーレベルの低下がより顕著となる ${ }^{4) 5) 。}$

4）亜急性甲状腺炎，無痛性甲状腺炎などにおいても病変部にエコーレベルの低下が認められる

(図 1） ${ }^{67)}$ 。ドップラー法を用いた血流動態の検索によりバセトウ病とこれらの甲状腺炎による甲 状腺中毒症の鑑別が可能との報告もみられる ${ }^{8)}$ 。

一方, 前頝部に結節をみとめる場合 US は甲状腺腫瘍の検出およびその囊胞性変性の有無の評価 にきわめて有用である。腫瘍が良性か悪性かの鑑別は(1)腫瘤の形態, (2)辺縁低エコー体（ハロー） の有無, 性状, (3)内部エコー像, (4)周囲への浸潤像やリンパ節腫大の有無などからある程度は可能 であり，このような診断基準で70-90\%の正診率が得られる。腺腫は通常，境界が鮮明で平滑な円 形ないし棈円形の腫瘤として描出され，均一で途切れのない薄い八ローを持つことが多い。ただし 甲状腺癌でも特に小さい症例では同様の所見を示すことがあるので注意が必要である。内部エコー

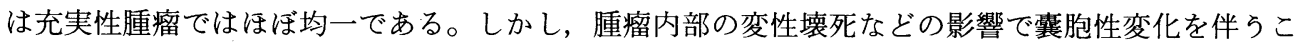
とが多い（図 2）。結節性病変が 2 個以上, あるいは両葉に存在する場合, 大部分は腺腫様甲状腺 腫である。この場合霬胞性変性や粗大な石灰化像, 不均一な内部エコーなど多彩な所見を認めるの が特徴的所見である。 
甲状腺癌では乳頭癌, 次に濾胞癌が多く, 髄様癌や未分化癌は稀である。乳頭癌ではエコーレベ ルが低く，不整な形態のものが多い。不規則に大きく進展しているものでは悪性の診断は容易であ る。上述の八ローは必ずしも良性腫瘍に特異的な所見ではなく，特に八ローの厚さが不均一で途切 れている場合や八ローを越える浸潤像がある場合には悪性が強く示唆される。腫瘤の内部エコーは 不規則，不均一である。腫瘤に砂粒状の小石灰化（砂粒腫小体 psammoma body）による strong spotty echo が混在している場合には乳頭癌が強く疑われる（図 3）。この微細な石灰化は音響陰 影を伴わないことが多い。癌に囊胞変性を来すことも少なくない。囊胞以外の実質部が乳頭状に増 殖し, strong spotty echo を伴う場合には乳頭癌が強く疑われる9)。気管，筋肉，血管などへの浸 潤像や頝部リンパ節腫大は，頻度はあまり高くはないが，甲状腺癌に特徽的な所見である。

濾胞癌は病理学的にも濾胞腺腫との鑑別が困難なことが多い。超音波所見でも特に被膜浸潤や血

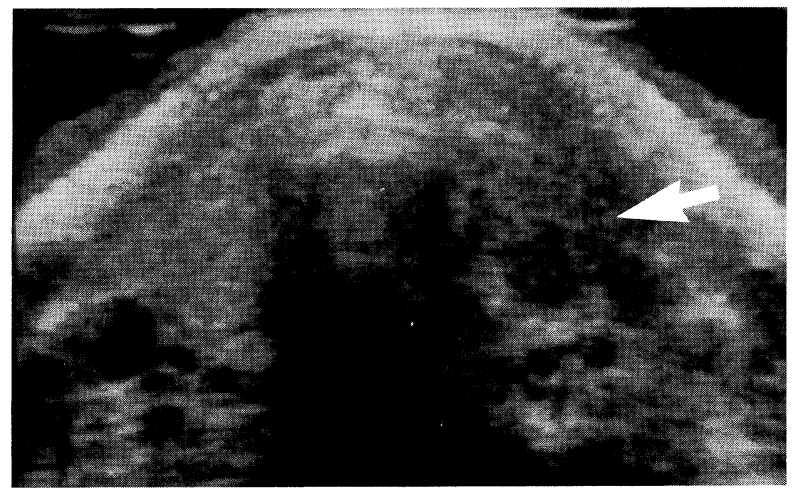

図1．亜急性甲状腺炎の超音波断層像

甲状腺左葉の病変部にエコーレベルの低下が認められる。

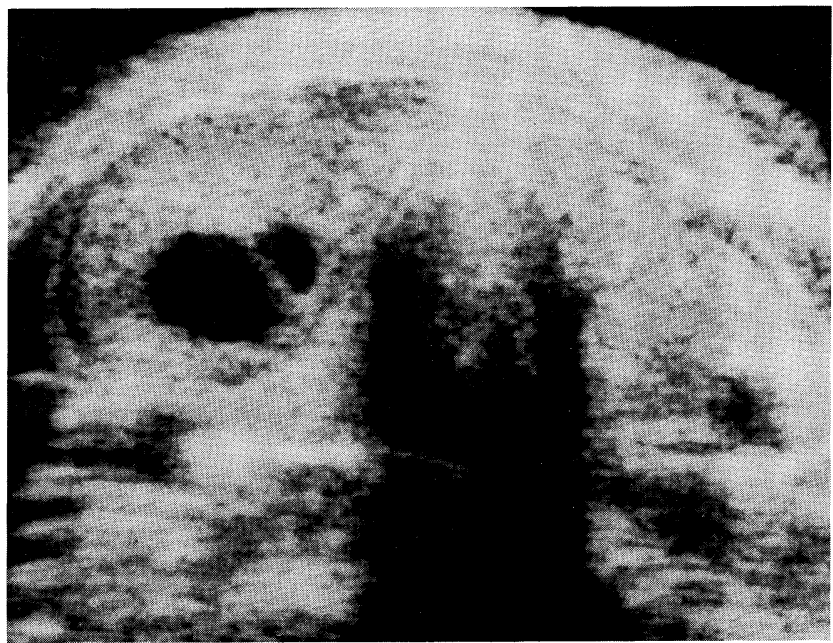

図2。甲状腺腺腫の超音波断層像

甲状腺右葉に類円形で平滑な腫瘤を認める。霬胞状変性部（２ヶ）を除き 内部エコーは均一で周辺に低エコー帯（halo）がみられる。 
管内浸潤のないものでは両者の鑑別は非常に難しい。䯣様癌では比較的粗い石灰化エコーが多数認 められる傾向がある。未分化癌は進展が非常に速く, エコーレベルは乳頭癌や前頝筋のそれより低 い。石灰化を伴い周囲への浸潤像が認められることが多い(10)。

悪性リンパ腫は境界鮮明な低エコ一腫瘤として描出され, 典型的な症例では超音波診断は容易で

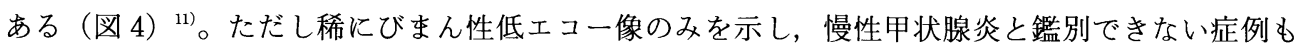
ある ${ }^{12)}$ 。

2. ${ }^{123} \mid$ または ${ }^{99 \mathrm{~m} T C ~ シ ン チ ク ゙ ラ フ ィ ~}$

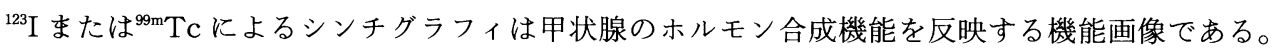
従ってシンチグラフィの撮影と同時に撕取率を計算して診断に役立てる。びまん性甲状腺腫の場合

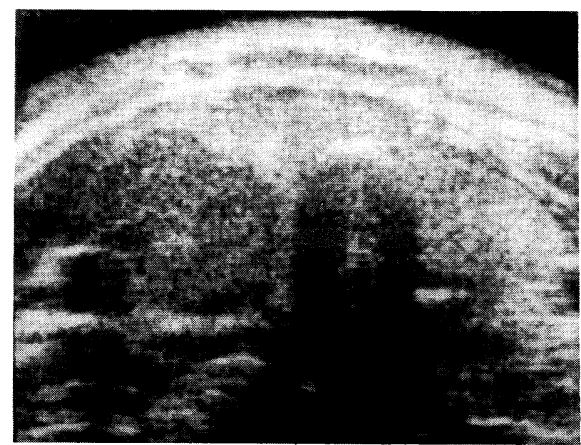

図3，乳頭癌の超音波断層像

右葉に辺縁不整, 低エコーの腫瘤を認め, 内部に高エコー レベルを示す微少石灰化像が散在ししている。

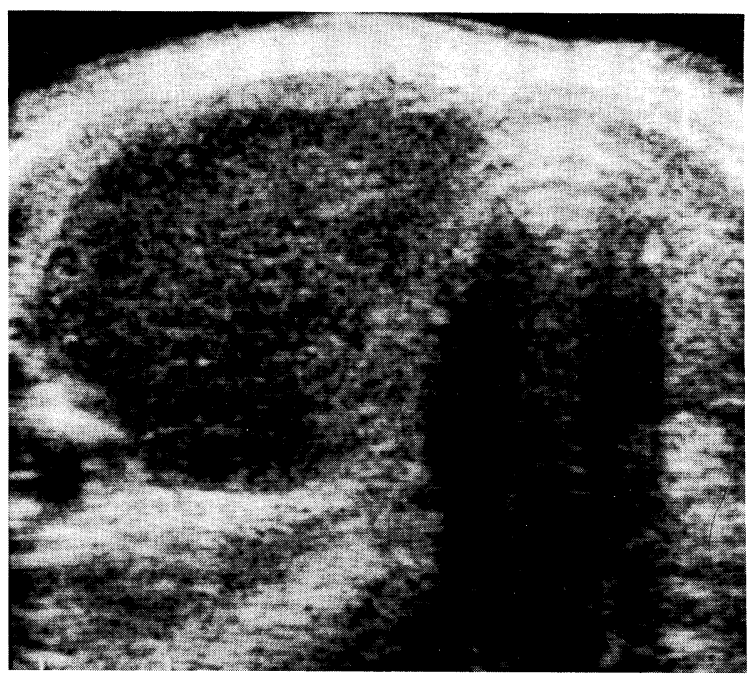

困4．悪性リンパ腫の超音波断層像

右葉全体を占める境界明膫で低エコ一の腫瘤を認める。 
に最も重要なのは甲状腺中毒症の鑑別診断である。バセドウ病と同様に血中甲状腺ホルモンが高値 を示す破壊性甲状腺中毒症（亜急性甲状腺炎や無痛性甲状腺炎）は摂取率が著しい低值となること で診断される。また軽症バセドウ病の診断や治癒判定には $\mathrm{T}_{3}$ 抑制試験が用いられている。一方, 結節の場合にははその機能がチェックできる。腫瘍の多くは機能をもたず，欠損像 (cold nodule) を示す。しかし，機能性腺腫，特に過機能性腺腫（Plummer 病）では健常部よりも高い摄取率を 示す warm nodule，ないしは健常部への取り込みを認めない hot nodule として描出される。な お ${ }^{99 \mathrm{~m}} \mathrm{TcO}_{4}^{-}$（過テクネチウムイオン）ではイオン捕獲能のみしか検出できないので，真に機能を有

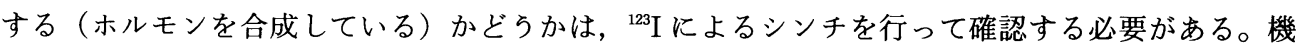
能性腫瘍はそのほとんどが良性であるのに比し， cold noduleの良・悪性は大きな結節の場合を除 き，シンチ上からは鑑別が困難である。

\section{3. 第二段階の画像診断法}

\section{1）頚部 $X$ 線}

US にて腫瘤内に石灰化を認めるときは，軟 X 線による頝部側面撮影によりその性状をさらに検 討するのがよい。上述のごとく粗大な石灰沈着は癌に限らず，良性結節，特に腺腫様甲状腺腫など で認められるが，微細な砂粒腫小体様陰影がみられるときは乳頭癌である可能性が高い沼。髄様癌 では原発巣のみならず転移巣にも多数の粗大斑状陰影が集まって認められる。一方，頝部の高圧 $\mathrm{X}$ 線正面撮影では気管の圧排の有無, 癌の浸潤による気管壁の不整や気管の狭窄の有無がチェック できる。

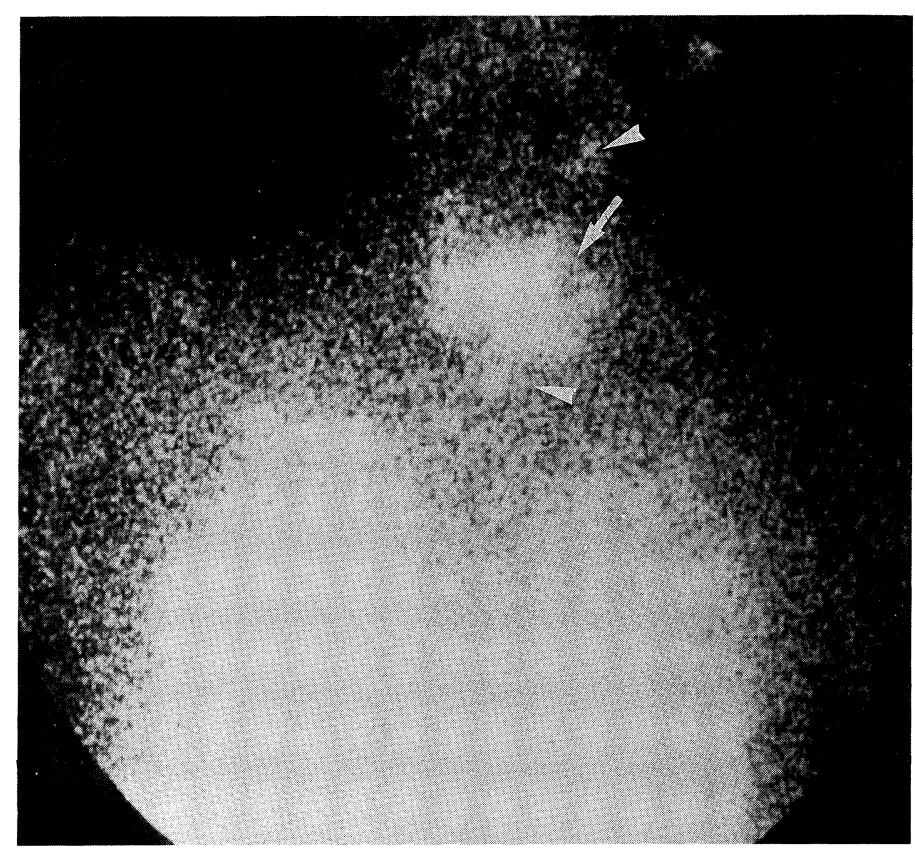

図5，乳頭癌の頸部リンパ節および肺転移例における ${ }^{201} \mathrm{Tl}$ シンチグラム

${ }^{99 m} \mathrm{Tc}$ シンチグラムでは左葉に欠損がみられた。左葉の結節（矢印）と両肺野に強い， ${ }^{201} \mathrm{~T} 1$ の集積が認められる。ほかに左頸部リンパ節, 上縦隔の転移巣にも ${ }^{201} \mathrm{~T} 1$ の 集積がみられる（矢頭）。 


\section{2) 腫瘍シンチグラフィ}

甲状腺癌の診断のためにはいくつかの腫瘍シンチグラフィーが行われている。 ${ }^{201} \mathrm{~T} 1$-塩化タリウ ムの集積（特に 2〜4 時間後の delayed image での集積）は癌に多くみられるが ${ }^{14)}$ ，増殖傾向の強 い腺腫でもみられることがあり，特異性が高くない。しかし，このシンチは頝部リンパ節転移や遠 隔転移巣の描出に優れ（図 5） ${ }^{15116)}$, 胸郭内への進展など腫瘍の浸潤範囲の検索や手術後の再発の 検出 ${ }^{17)}$ などにも有用である。より特異的な甲状腺癌の遠隔転移巣の検索のためには ${ }^{131} \mathrm{I} 37 \sim 111 \mathrm{MBg}$ （1３mCi）の投与による全身シンチが行われる。分化型腺癌，ことに濾胞癌では肺，骨などの転 移巣が ${ }^{131} \mathrm{I}$ の集積能を示す。乳頭癌などで最初に集積がみられない場合でも原発巣の根治手術に際 し, 甲状腺全摘出術を行うと転移巣に ${ }^{131} \mathrm{I}$ の集積を認めるようになることが多い。 ${ }^{131} \mathrm{I} の$ 集積がみら れた場合には ${ }^{131} I$ 大量投与による治療の適応となる。なお甲状腺癌の骨転移巣は骨シンチグラフィ

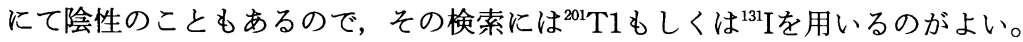

急速な腫瘤の増大など未分化癌の可能性が考穴られるときは， ${ }^{67} \mathrm{Ga}$ ークエン酸ガリウムによるシ ンチグラフィーを行う。 ${ }^{67} \mathrm{Ga}$ の集積がみられるのは未分化癌のほか, 悪性リンパ腫である ${ }^{18)}$ 。慢性 甲状腺炎でもびまん性に集積がみられるが，上記腫瘍とは臨床経過および甲状腺腫の性状が異なる。 ただし甲状腺全体にびまん性に浸潤した悪性リンパ腫の場合，橋本病との鑑別が難しいことがある 12)。

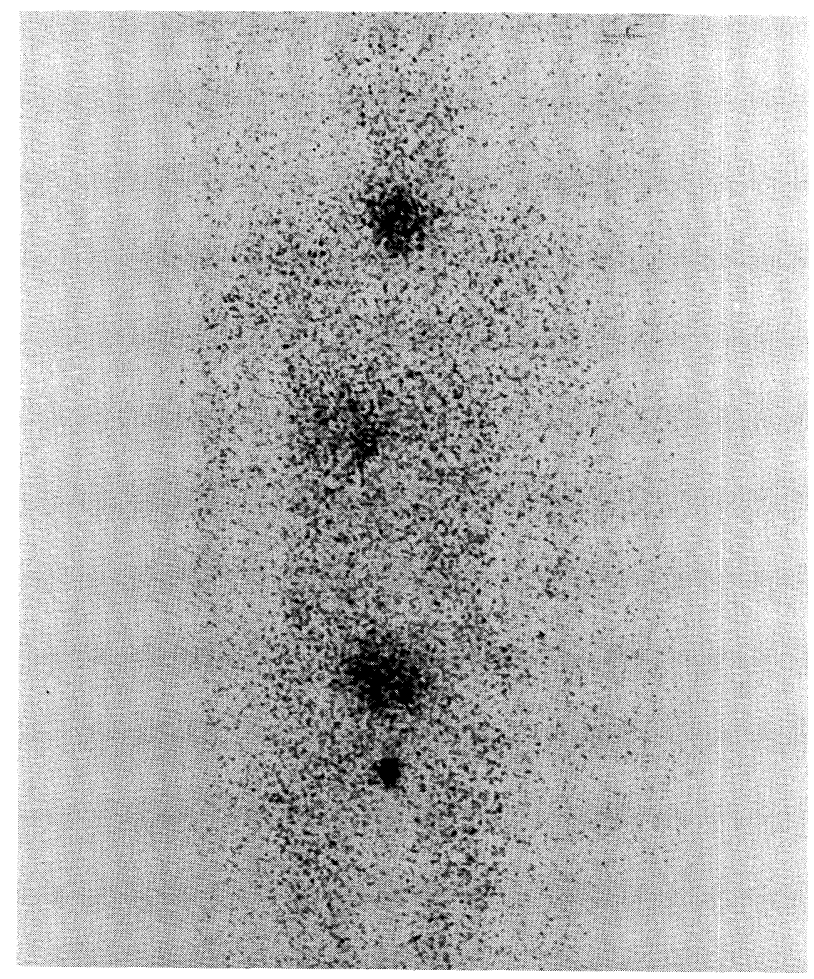

図6. Sipple 症候群における ${ }^{13} \mathrm{I} I-\mathrm{MIBG}$ シンチグラフィ。右副腎褐色細胞腫のみ ならず，右頸部の䯣様癌にも集積が認められる。 
特異な石灰化を伴う髄様癌では血中カルシトニンやCEA の測定がその診断に有用である。シン チグラフィーとしては ${ }^{99 m} \mathrm{~T}$ c-MDP (methylene diphosphonate) の集積が知られていたが, 最近褐 色細胞腫に用いられる ${ }^{131} I$ - metaiodobenzyl guanidine (MIBG) の集積が高率にみられることが明 らかにされた（図 6) ${ }^{199}$ 。また5価の ${ }^{99 \mathrm{~m}} \mathrm{Tc}$ イオンを用いた ${ }^{99 \mathrm{~m}} \mathrm{Tc}(\mathrm{V})$ - dimercaptosuccinic acid (DMS) がこの腫瘍に特異的に集積することが知られている（図 7） ${ }^{20)}$ 。

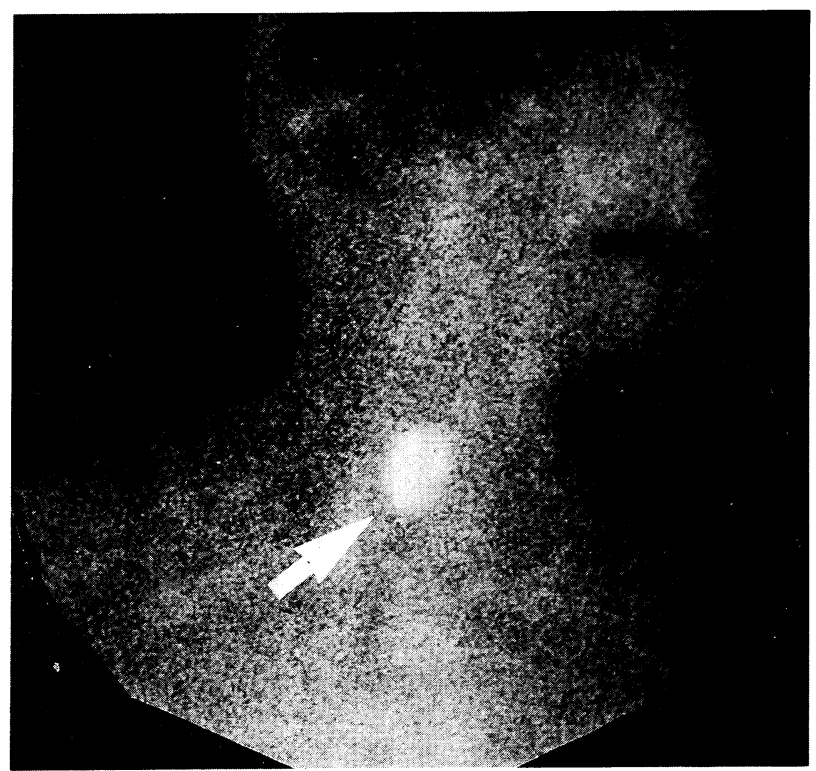

四7. 䯣様癌への ${ }^{9 m} \mathrm{Tc}(\mathrm{V})$ - DMSの強い集積

\section{3） X 線 CT}

甲状腺腫瘍の周囲への進展, 頝部の血管や気管, 食道との関係を把握する上では X 線 CT が役 立つ。触診のみでは広がりの範囲の確認が困難な大きい腯瘍, 手術後の症例や, 糈隔へ進展してい る症例なとでは, 特に有用である。

\section{4) 磁気共鳴画像 (MRI)}

最近急速に普及してきた MRI は，CT やUS と異なり，骨や空気によるアーチファクトがない こと, 血管の同定が容易なこと, 任意の断面が得られることなど, 局在診断においても有利な点を もつ他，原理的に水素原子の様々な化学的変化を反映する画像であることより，質的診断における 有用性も注目されている。

超電導高磁場装置にて表面コイルを用いて撮像すると, 分解能, 組織コントラストのいずれにお いても X 線 CT より優れた画像が得られる ${ }^{21)}$ 。甲状腺の信号強度は縦緩和時間 (T1) 強調像で脂肪 よりも低く, 筋肉よりもやや高い。横緩和時間 (T2) 強調像ではそのどちらよりも高い信号強度を 示し周囲組織より容易に分離同定できる。正常部と比べると腫瘍は良性, 悪性を問わず T1強調像 で等〜高信号, T2強調像で高信号を示す。このため信号強度の変化から良・悪性の鑑別はできな ( ${ }^{22}$ 。しかし，円滑な辺縁をもつ腺腫ではその周辺に低信号の偽被膜構造を認めることが多い（図 8）。一方，この偽被膜の不規則性や断裂所見は悪性を示唆する。この点では MRIが最も詳細な 
情報を与えるものと考兄られる（図 9） ${ }^{23)}$ 。特に冠状断の T1強調像は頭・尾側への浸潤所見および リンパ節腫大の評価に有用である。線維組織との信号強度の違いから術後の再発を検出するのにも 有用と考えられる ${ }^{24)}$ 。現在のところ機器が高価であり，撮影時間が長いのが欠点であるが，今後の 改良により, 近い将来 X 線 CT に取って代わるものと考兄られる。さらに MR スペクトロスコピー の実用化などにより全く新しい診断情報をもたらすことも期待される。

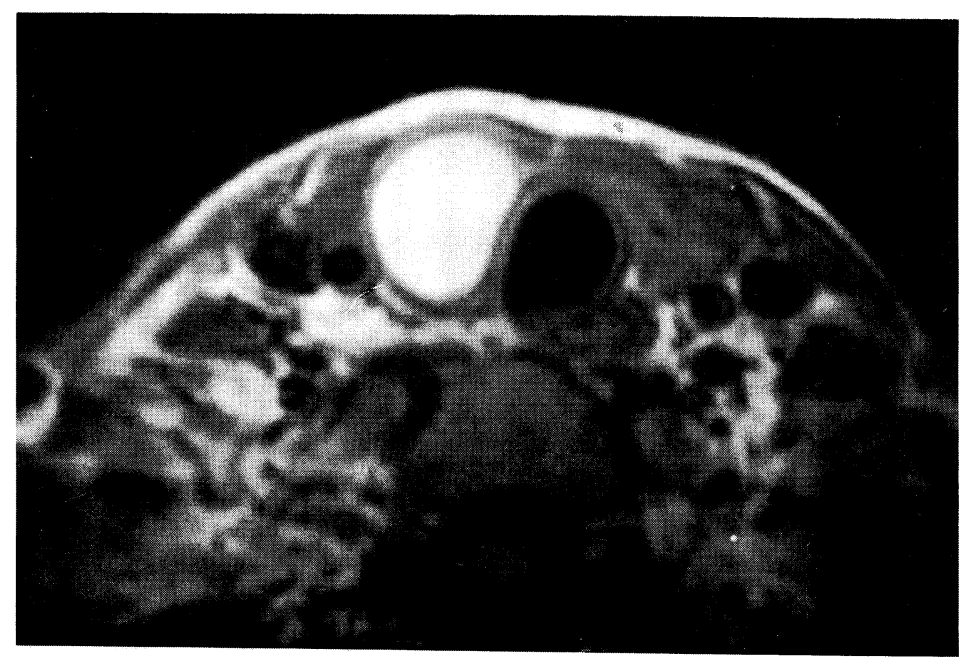

図8. 腺腫の $\mathrm{T} 1$ 強調像

右葉に辺縁平滑な腫瘤を認め, 内部は出血による裏胞状変性のため均質な高信号を

呈している。偽被膜は気管軟骨と同程度の低信号部として認識される。

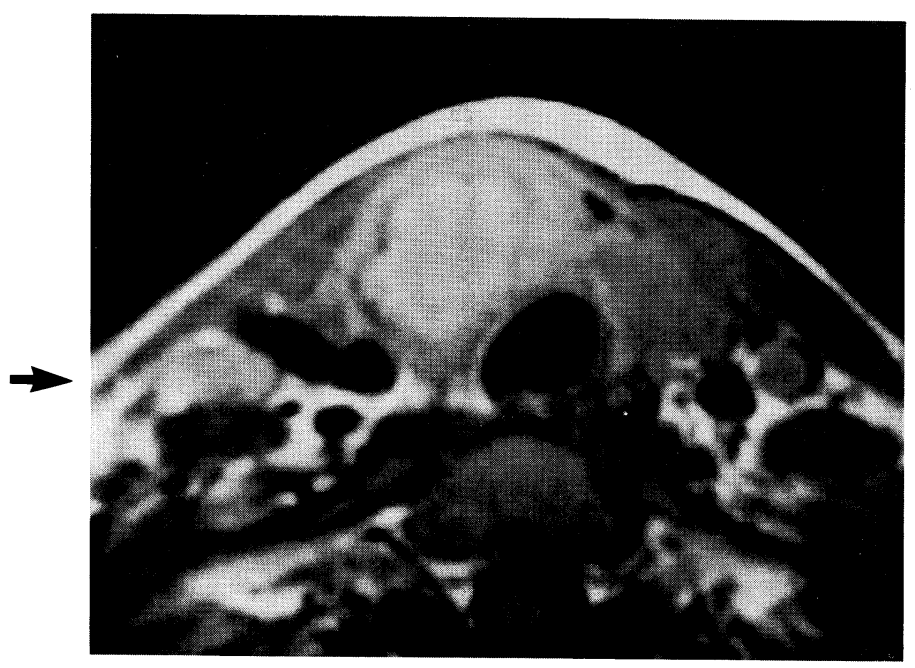

図9. 乳頭癌の $\mathrm{T} 1$ 強調像

右葉に辺縁不整な腫慮を認める

偽被膜は不規則で部分的に断裂がみられる。右頸部リンパ節に転移巣を認める(矢印)。 
おわりに

US の進歩と普及により甲状腺疾患の画像診断法は著しい变貌を遂げてきた。USによるスクリー ニングを行った後, 機能情報をシンチグラフィで補い, 必要に応じて吸引細胞診を行らことで多く の場合診断が確定でさる。さらに腫瘍の種類, 広がりの評価や良・悪性の鑑別のために腫瘍シンチ グラフィ，X線 CT, MRI などがそれぞれの特徵を生かして活用されているが，な㧍小腫瘤の良・ 悪性の鑑別には限界があり，今後の課題として残されている。

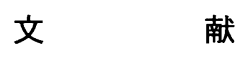

1) Simeone, J.F., Daniels, G.H., Mueller, P.R., Maloof, F., van Sonnenberg, E., Hall, D.A., O' Connell, R., Ferruci, J.T. and Wittenberg, J.: High-resolution real-time sonography of the thyroid. Radiology, 1982; 145: 431-435.

2 ) 山本和高, 日高昭斉, 德田康孝, 幡生寛人, 飯田泰啓, 笠木寛治: 甲状腺・頸部の超音波診断. 小西淳二編，金芳堂，京都，1990;7-117.

3 ) Yokoyama, N., Nagayama, Y., Kakezono, F., Kiriyama, T., Morita, S., Ohtakara, S., Okamoto, S., Morimoto, I., Izumi, M., Ishikawa, N., Ito, K. and Nagataki, S.: Determination of the volume of the thyroid gland by a high resolutional ultrasonic scanner. J. Nucl. Med., 1986; 27: 1475-1479.

4 ) Yoshida, A., Adachi, T., Noguchi, T., Urabe, K., Onoyama, S., Okamura, Y., Shigemasa, C., Abe, K. and Mashiba, H.: Echographic findings and histological feature of the thyroid: A reverse relationship between the level of echo-amplitude and lymphocytic infiltration. Endocrinol. Japon., 1985; 32: 681-690.

5 ) Hayashi, N., Tamaki, K., Konishi, J., Yonekura, Y., Senda, M., Kasagi, K., Yamamoto, K., Iida, Y., Misaki, T., Endo, K., Torizuka, K. and Mori, T.: Sonography of Hashimoto's thyroiditis. J. Clin. Ultrasound, 1986; 14: 123-126.

6 ) Blum, M., Passalaqua, A.M., Sackler, J.P. and Pudlowski, R.: Thyroid echography of subacute thyroiditis. Radiology, 1977; 125: 795-798.

7 ) Tokuda, Y., Kasagi, K., Iida, Y., Yamamoto, K., Hatabu, H., Hidaka, A., Konishi, J. and Ishii, Y.: Sonography of subacute thyroiditis: Changes in the findings during the course of the disease. J. Clin. Ultrasound, 1990; 18: 21-26.

8 ）長倉穂積, 川内章裕, 伴 良雄, 海原正宏, 原 秀雄, 福成信博, 九島健二, 谷山松雄, 百渓尚子, 伊藤国彦：甲状腺中毒症の鑑別における甲状腺血流測定の有用性の検討. 超音波医 学, 1988; 16, Supplement I: 475-483.

9 ) Hatabu, H., Kasagi, K., Yamamoto, K., Iida, Y., Misaki, T., Hidaka, A., Shibata, T., Shoji, K., Higuchi, K., Yamabe, H., Endo, K. and Konishi, J.: Cystic papillary carcinoma of the thyroid gland: A new sonographic sign. Clin. Radiol., 1991; 43: $121-124$.

10) Hatabu, H., Kasagi, K., Yamamoto, K., Kubo, S, Higuchi, K., Hidaka, A., Misaki, T., Iida, Y., Sakahara, H., Yamabe, H., Endo, K. and Konishi, J.: Undifferentiated carcinoma of the thyroid gland: Sonographic findings. Clin. Radiol., 1992; 45: 
$307-310$.

11) Perulekar S.G. and Katzman, R.A.: Primary malignant lymphoma of the thyroid: Sonographic appearance. J. Clin. Ultrasound, 1986; 14:60-62.

12) Kasagi, K., Hatabu, H., Tokuda, Y., Yamabe, H., Hidaka, A., Yamamoto, K., Iida, Y., Misaki, T., Mori, T., Endo, K. and Konishi, J.: Lymphoproliferative disorders of the thyroid gland: radiological appearances. Brit. J. Radiol., 1991; 64: $569-575$.

13) Akisada, M. and Fujimoto, Y.: Soft tissue roentgenography in diagnosis of thyroid cancer-Detection of psammoma bodies by spot-tangential projection. Igaku Shoin, Tokyo, 1973.

14) Ochi, H., Sawa, H., Fukuda, T., Inoue, Y., Nakajima, H., Masuda, Y., Okamura, T., Onoyama, Y., Sugano, S., Ohkita, H., Tei, Y., Kamino, K. and Kobayashi, Y.: Thallium-201-chloride scintigraphy to evaluate benign and/or malignant nodules. Usefulness of the delayed scan. Cancer, 1982; 50:236-240.

15) Tonami, N., Bunko, H., Michigishi, T., Kawajima, A. and Hisada, K.: Clinical application of ${ }^{201} \mathrm{~T} 1$ scintigraphy in patients with cold thyroid nodules. Clin. Nucl. Med., 1978; 3: 217-221.

16) Fukuchi, M., Tachibana, K., Kuwata, M., Nishikawa, A., Hyodo, K., Okamoto, E. and Nagai, K.: Thallium imaging in thyroid carcinoma: Appearance of lymphnode metastasis. J. Nucl. Med., 1978; 19: 195-196.

17) Iida, Y., Hidaka, A., Hatabu, H., Kasagi, K. and Konishi, J.: Follow-up study of postoperative patients with thyroid cancer by thallium-201 scintigraphy and serum thyroglobulin measurement. J. Nucl. Med., 1991; 32: 2098-2100.

18) Higashi, T., Ito, K., Mimura, T., Ohi, T., Nishikawa, Y. and Wilcox, J.R.: Clinical evaluation of ${ }^{6} \mathrm{Ga}$-scanning in the diagnosis of anaplastic carcinoma and malignant lymphoma of the thyroid. Radiology, 1981; 141: 491-497.

19) Ohta, H., Yamamoto, K., Endo, K., Mori, T., Hamanaka, D., Shimazu, A., Ikekubo, K., Makimoto, K., Iida, Y., Konishi, J., Morita, R., Hata, N. , Horiuchi, K., Yokoyama, A., Torizuka, K. and Kuma, K.: A new imaging agent for medullary carcinoma of the thyroid. J. Nucl. Med., 1984; 25: 323-325.

20) Endo, K., Shiomi, K., Kasagi, K., Konishi, J., Torizuka, K., Nakao, K. and Tanimura, H.: Imaging of medullary thyroid cancer with ${ }^{131} \mathrm{I}-\mathrm{MIBG}$. Lancet, 1984; 2 : 233.

21) Gefter, W.B., Spritzer, C.E., Eisenberg, B., LiVolsi, V.A., Axel, L., Velchik, M. , Alavi, A., Schenck, J. and Kressel, H.Y.: Thyroid imaging with high-field strength surface-coil MR. Radiology, 1987; 164: 483-490.

22) Noma, S., Nishimura, K., Togashi, K., Itoh, K., Fujisawa, I., Nakano, Y., Konishi, J., Kasagi, K., Iida, Y., Itoh, H. and Torizuka, K.: Thyroid gland: MR imaging. Radiology, 1987; 164: 495-499. 
23) Noma, S., Kanaoka, M., Minami, S., Sagoh, T., Yamashita, K., Nishimura, K., Togashi, K., Itoh, K., Fujisawa, I., Nakano, Y., Oomura, M., Tasaka, Y., Itoh, H. and Konishi, J.: Thyroid masses: MR imaging and pathologic correlation. Radiology, 1988; $168: 759-764$.

24) Auffermann, W., Clark, O.H., Thurnher, S., Galante, M. and Higgins, C.B.: Recurrent thyroid carcinoma: Characteristics on MR images. Radiology, 1988; 168: 753-757. 